\title{
Effect of external pH on cyanobacterial phycobiliproteins production and ammonium excretion
}

\author{
Ojit Singh Keithellakpam ${ }^{1 *}$, Tiwari Onkar Nath ${ }^{1}$, Avijeet Singh Oinam ${ }^{1}$, Indrama Thingujam ${ }^{1}$, Gunapati Oinam ${ }^{1}$, \\ Sharma Gauri Dutt ${ }^{2}$ \\ ${ }^{1}$ Freshwater Cyanobacterial and Microalgal Repository, Microbial Resources Division, Institute of Bioresources and Sustainable Development (A National \\ Institute of DBT, Govt. of India) Takyelpat, Imphal-795001, Manipur, India. ${ }^{2}$ Department of Life Science and Bio-informatics, Hargobind Khurana School \\ of Life Sciences, Assam University, Silchar-788011, Assam, India.
}

\begin{tabular}{l} 
ARTICLE INFO \\
\hline Article history: \\
Received on: $06 / 07 / 2015$ \\
Revised on: $16 / 07 / 2015$ \\
Accepted on: $02 / 08 / 2015$ \\
Available online: $24 / 08 / 2015$ \\
\hline Key words: \\
Cyanobacteria, Loktak Lake, \\
pH, Phycobiliproteins, \\
Ammonium excretion
\end{tabular}

\begin{abstract}
In the present study, cyanobacterial strains isolated from Loktak Lake were investigated for their possibility of increasing the content of phycobiliproteins and ammonium excretion under different levels of $\mathrm{pH}$. At $\mathrm{pH} 5.0$, maximum amount of PE was observed in Nostoc sp. BTA-61 (111.10 $\left.\pm 9.43 \mu \mathrm{gmg}^{-1}\right)$. Maximum PC was expressed in Phormidium sp. BTA-1048 (155.17 $\left.\pm 10.15 \mu \mathrm{gmg}^{-1}\right)$. APC content was observed maximum in Nostoc commune BTA-67 $\left(81.45 \pm 7.68 \mu \mathrm{gmg}^{-1}\right)$. At pH 6.0, high PE was observed in Nostoc sp. BTA-61 (125.11 \pm 11.60 $\left.\mu \mathrm{gmg}^{-1}\right)$. PC was maximum in Phormidium sp. BTA-1048 $\left(168.15 \pm 9.58 \mu \mathrm{gmg}^{-1}\right)$. APC was highest in Nostoc commune BTA-67 $\left(91.41 \pm 2.88 \mu \mathrm{gmg}^{-1}\right)$. Regarding at $\mathrm{pH} 7.0$, PE was found in high quantity in Nostoc sp. BTA$61\left(127.91 \pm 14.91 \mu^{-1} \mathrm{gmg}^{-1}\right)$. PC was maximum in Nostoc commune BTA-67 $\left(128.52 \pm 5.66 \mu \mathrm{gmg}^{-1}\right)$. APC was highest in Nostoc commune BTA-67 $\left(96.40 \pm 3.52 \mu \mathrm{gmg}^{-1}\right)$. $\mathrm{pH} 8.0$ showed high PE content in Nostoc sp. BTA-61 $\left(115.75 \pm 6.27 \mathrm{\mu mg}^{-1}\right)$. PC was highest in Phormidium sp. BTA-1048 $\left(160.09 \pm 10.56 \mu \mathrm{gmg}^{-1}\right)$. APC was maximum in Nostoc commune BTA-67 $\left(84.15 \pm 5.30 \mu \mathrm{gmg}^{-1}\right)$. $\mathrm{pH} 9.0$ showed maximum PE content in Nostoc $\mathrm{sp}$. BTA-61 $\left(95.39 \pm 4.87 \mu \mathrm{gmg}^{-1}\right)$. PC was high in Phormidium sp. BTA-1048 $\left(148.13 \pm 9.20 \mu \mathrm{gmg}^{-1}\right)$. APC was highest in Nostoc commune BTA-67 $\left(77.43 \pm 5.78 \mu \mathrm{gmg}^{-1}\right)$. PE, PC and APC concentration was significantly higher (LSD test, $p<0.05$ ) in $\mathrm{pH} 7.0$ when compared with the other $\mathrm{pH} 5.0,6.0,8.0$ and 9.0. In this study, maximum ammonium excretion was observed in Nostoc muscorum BTA-950 in all the different $\mathrm{pH}$ and minimum in Anabaena sp. BTA-964. The findings indicates that these cyanobacterial strains may be proved as promising microorganism for the phycobiliproteins production and ammonium excretion which could be exploited biotechnologically for the benefit of commercial applications.
\end{abstract}

\section{INTRODUCTION}

Cyanobacteria are photoautrophic prokaryotes which are known for their remarkable ability to grow and survive in varying environmental conditions [1]. They are known to produce a variety of water soluble photosynthetic pigments. These pigments could be used as natural colorants for food and cosmetic products as well as molecular fluorescent markers, depending on their purity grade [2]. The use of phycobiliproteins as non-toxic and non-carcinogenic natural food colorants is gaining importance because of the potential toxicity and carcinogenicity of the currently used synthetic food colourants or additives [3]; [4]. The prices of phycobiliproteins vary from US\$ $3-25 \mathrm{mg}^{-1}$ for food/cosmetic grade pigments but they can reach

\footnotetext{
* Corresponding Author

Ojit Singh Keithellakpam, Microbial Resources Division Institute of Bioresources and Sustainable Development (A National Institute of DBT, Govt. of India) Takyelpat, Imphal-795001, Manipur, INDIA Email: ojit1999@gmail.com
}

US\$ $1500 \mathrm{mg}^{-1}$ for highly purified molecular markers (with antibodies or other fluorescent molecules). In 1997, the value of these pigments in the commercial sector was estimated to be US\$ 50 million worldwide [5]. Currently, nutraceuticals segment of food industry is exploring. This market is growing at 5\% per annum and is estimated at between $\$ 6$ billion USD and $\$ 60$ billion USD in today's global market [6]. The utilizing cyanobacteria as an efficient source of biofertilizer for rice field has been practised and adopted in India [7]. Among the different soil factors affecting the survival of cyanobacteria, $\mathrm{pH}$ is particularly important directly influencing cyanobacterial distribution and abundance in soil [8]. Use of biofertilizers is cost-effective, cheap and renewable source to supplement the chemical fertilizers. $\mathrm{pH}$ plays a very important role in the metabolic and physiological activities of cyanobacteria. It strongly affects biomass production, chemicals dissociation and cell physiology. As with any other living cells, cyanobacterial cell function depends on the maintenance of a narrow range of survivable intracellular $\mathrm{pH}$ [9]. Cyanobacteria are capable of maintaining a constant internal $\mathrm{pH}$ of 7.1-7.5 in the range of external $\mathrm{pH}$ from 5.0 to 10 [10]. 
Research on cyanobacterial pigment production originating in different habitats and effects of environmental factors on its content could contribute on the understanding of cyanobacteria-specific acclimation processes and responses to changes of environmental conditions. On the other hand, it could be very important for optimization of cyanobacterial production of biotechnologically valuable chemicals, such as pigments [11]; [12]. In the work presented here, we analyse the effect of different levels of $\mathrm{pH}$ in phycobiliproteins production and ammonium excretion of the cyanobacterial strains isolated from freshwater habitats of Loktak Lake.

\section{MATERIALS AND METHODS}

\subsection{Cyanobacterial strains}

Cyanobacterial strains used in the present study were isolated from freshwater habitats of Loktak Lake located in Manipur, India and is the largest freshwater wetland in the NorthEastern region of India. They were identified referring to monograph [13] and were deposited to Freshwater Cyanobacterial and Microalgal Repository (National facility created by the Department of Biotechnology, Government of India with reference No. BT/PR 11323/PBD/26/171/2008 dated 31-03-2009), Institute of Bioresources and Sustainable Development (IBSD), Imphal, Manipur, India.

\subsection{Growth conditions}

Cyanobacterial strains were optimized for its growth and high yield production of phycobiliproteins and ammonium excretion from it. In order to assess the influence of $\mathrm{pH}$ on the phycobiliprotein production and ammonium excretion, the $\mathrm{pH}$ of the BG-11 medium [14] was adjusted at 5.0, 6.0, 7.0, 8.0 and 9.0 using $1 \mathrm{~N} \mathrm{HCl}$ and $1 \mathrm{~N} \mathrm{NaOH}$. Dried cyanobacterial biomass of 10 $\mathrm{mg}$ was inoculated into $100 \mathrm{ml}$ of sterile BG-11 medium in $150 \mathrm{ml}$ cotton-plugged Erlenmeyer flask. Experimental strains were maintained at $28 \pm 2^{\circ} \mathrm{C}$ under illumination by cool white fluorescent light of intensity 54-67 $\mu \mathrm{mol}$ photons $\mathrm{m}^{-2} \mathrm{~s}^{-1}$ with a $14: 12 \mathrm{~h}$ light:dark conditions.

\subsection{Phycobiliproteins estimation}

The content of phycobiliproteins (PC, PE, and APC) was determined using a spectrophotometric method [15].

\subsection{Ammonium determination}

The amount of ammonium concentration in the medium was measured by Solorzano's phenol-hypochlorite method [16]. All the experiments were carried out in triplicates and the data were presented as mean values \pm SD of three replicates.

\section{RESULTS AND DISCUSSION}

Quantitative analysis of PE, PC and APC against different levels of $\mathrm{pH}$ was presented (Fig 1a-1j). At $\mathrm{pH} 5.0$, maximum amount of PE was observed in Nostoc sp. BTA-61 $\left(111.10 \pm 9.43{\mu \mathrm{gmg}^{-1}}^{-}\right)$and minimum in Nostoc muscorum BTA950 $\left(0.13 \pm 0.09 \mu \mathrm{gmg}^{-1}\right)$. Maximum PC was expressed in Phormidium sp. BTA-1048 $\left(155.17 \pm 10.15 \mu \mathrm{gmg}^{-1}\right)$ whereas minimum was observed in Nostoc muscorum BTA950 $\left(0.75 \pm 0.03 \mu \mathrm{gmg}^{-1}\right)$. APC content was observed maximum in Nostoc commune BTA-67 $\left(81.45 \pm 7.68 \mu \mathrm{gmg}^{-1}\right)$ and minimum in Nostoc muscorum BTA-950 $\left(0.32 \pm 0.07 \mu \mathrm{gmg}^{-1}\right)$

Analysis in $\mathrm{pH}$ 6.0, high PE was observed in Nostoc sp. BTA-61 (125.11 $\left.\pm 11.60 \mu \mathrm{gmg}^{-1}\right)$ and minimum in Nostoc muscorum BTA-950 $\left(1.00 \pm 0.11 \mu \mathrm{gmg}^{-1}\right)$. PC was maximum in Phormidium sp. BTA-1048 (168.15 $\left.\pm 9.58 \mu \mathrm{gmg}^{-1}\right)$ and minimum in Nostoc muscorum BTA-950 (4.29 $\left.\pm 0.65 \mu \mathrm{gmg}^{-1}\right)$. APC was highest in Nostoc commune BTA-67 $\left(91.41 \pm 2.88 \mu \mathrm{gmg}^{-1}\right)$ and minimum in Nostoc muscorum BTA-950 $\left(2.17 \pm 0.12 \mu \mathrm{gmg}^{-1}\right)$.

At pH 7.0, PE was found in high quantity in Nostoc sp. BTA-61 $\left(127.91 \pm 14.91 \mu \mathrm{gmg}^{-1}\right)$ and minimum in Phormidium sp. BTA-52 $\left(2.11 \pm 0.43 \mu \mathrm{gmg}^{-1}\right)$. PC was maximum in Nostoc commune BTA-67 (128.52 $\left.\pm 5.66 \mu \mathrm{gmg}^{-1}\right)$ and minimum in Nostoc muscorum BTA-950 $\left(8.79 \pm 0.19 \mu \mathrm{gmg}^{-1}\right)$. APC was highest in Nostoc commune BTA-67 $\left(96.40 \pm 3.52 \mu \mathrm{gmg}^{-1}\right)$ and minimum in Nostoc muscorum BTA-950 $\left(5.90 \pm 0.69 \mu \mathrm{gmg}^{-1}\right)$.

At $\mathrm{pH}$ 8.0, high PE content was expressed in Nostoc sp. BTA-61 (115.75 $\left.\pm 6.27 \mu \mathrm{gmg}^{-1}\right)$ and minimum in Phormidium sp. BTA-52 $\left(1.05 \pm 0.26 \mu \mathrm{g} \mathrm{mg}^{-1}\right)$. PC was highest in Phormidium sp. BTA-1048 (160.09 $\left.\pm 10.56 \mu^{-1} \mathrm{gmg}^{-1}\right)$ and minimum in Nostoc muscorum BTA-950 (3.85 $\left.\pm 0.97 \mu \mathrm{gmg}^{-1}\right)$. APC was maximum in Nostoc commune BTA-67 $\left(84.15 \pm 5.30 \mu \mathrm{gmg}^{-1}\right)$ and minimum in Nostoc muscorum BTA-950 (1.25 $\left.\pm 0.15 \mu \mathrm{gmg}^{-1}\right)$.

At $\mathrm{pH}$ 9.0, maximum PE was observed in Nostoc sp. BTA-61 $\left(95.39 \pm 4.87 \mathrm{gmg}^{-1}\right)$ and minimum in Nostoc muscorum BTA-950 $\left(0.08 \pm 0.02 \mu \mathrm{gmg}^{-1}\right)$. PC was high in Phormidium sp. BTA-1048 (148.13 $\left.\pm 9.20 \mathrm{\mu gmg}^{-1}\right)$ and minimum in Nostoc muscorum BTA-950 $\left(0.63 \pm 0.08 \mu \mathrm{gmg}^{-1}\right)$. APC was highest in Nostoc commune BTA-67 (77.43 $\left.\pm 5.78 \mu \mathrm{gmg}^{-1}\right)$ and minimum in Nostoc muscorum BTA-950 $\left(0.11 \pm 0.09 \mu \mathrm{gmg}^{-1}\right)$. PE, PC and APC concentration was significantly higher (LSD test, $p<0.05$ ) in $\mathrm{pH}$ 7.0 when compared with the other $\mathrm{pH} 5.0,6.0,8.0$ and 9.0.

In this study, maximum ammonium excretion was observed in Nostoc muscorum BTA-950 in all the different $\mathrm{pH}$ and minimum in Anabaena sp. BTA-964 when compared to all the other cyanobacterial strains and were presented (Fig 2). In order to determine the impact of $\mathrm{pH}$ on phycobiliproteins production and ammonium excretion, cyanobacterial strains were exposed to different levels of $\mathrm{pH}$ 5.0-9.0. Among the different levels of $\mathrm{pH}$ applied, $\mathrm{pH} 7.0$ was found to be the best when compared to all the other four $\mathrm{pH}$. At $\mathrm{pH}-5.0$ and 9.0, the strains did not show proper growth. The increase in external $\mathrm{pH} 7.0-9.0$ significantly increased the total phycobiliprotein content in Nostoc sp. UAM 206 [17]. The content of pigments varied to a great extent depending on the strain and also on growth conditions. Although Nostoc and Anabaena are phylogenetically very close in origin [18], differences in their pigment content between the strains of both are evident, indicating a strain-specific property. Responses of microalgae to variation of environmental conditions could be done through cell changes or modulations of metabolism, and cellular 
compositions (acclimation response) or responses could be expressed through maintaining a balanced cell composition (homeostatic responses) [19]. Actually extreme buffer's pH cause internal electrostatic attraction by changing the charge on protein giving net positive charge and at this stage protein open up and bound solvent is lost, resulting denaturation of protein [20].
Accumulation of ammonia by living cells is highly dependent on $\mathrm{pH}$. However, it could comfortably grow over the $\mathrm{pH}$ range of 6.0-8.0. The data was in good agreement with the previous reports [21]; [22]. However, when the pHex (external $\mathrm{pH})$ fell below a certain value there was a significant decline in pHi (internal $\mathrm{pH}$ ), suggesting that acidic sensitivity might be

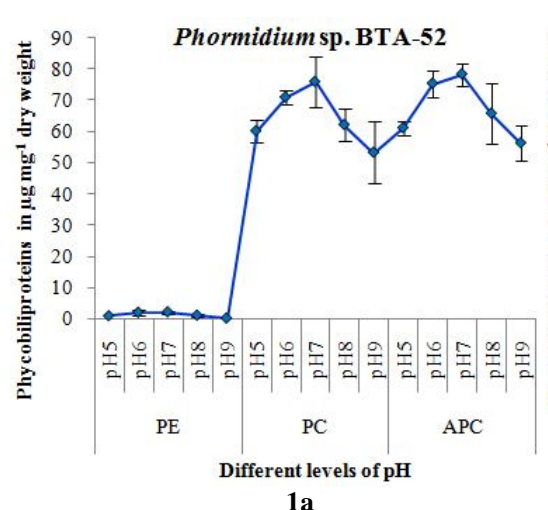

1a


$1 \mathrm{~g}$



PE



$1 \mathrm{e}$

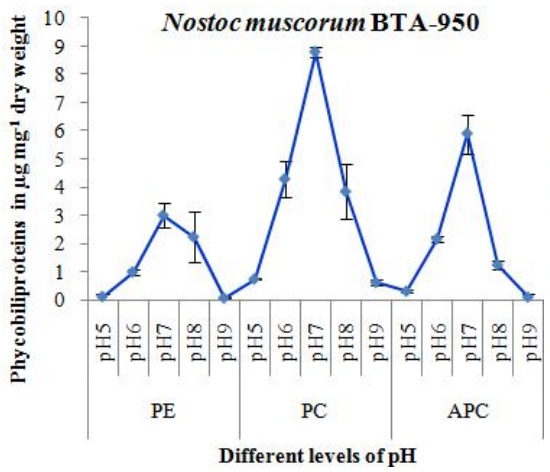

1h


1f

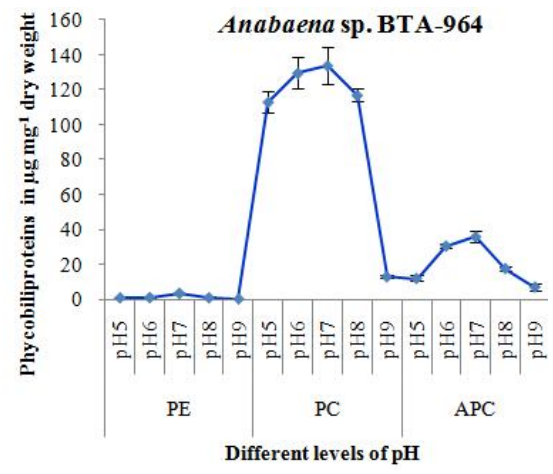

$1 i$

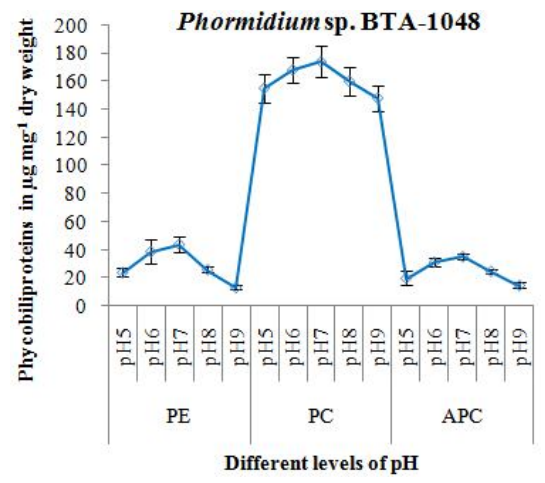

1J

Fig. 1a-1j: Effect of different $\mathrm{pH}$ levels on phycobiliproteins production 


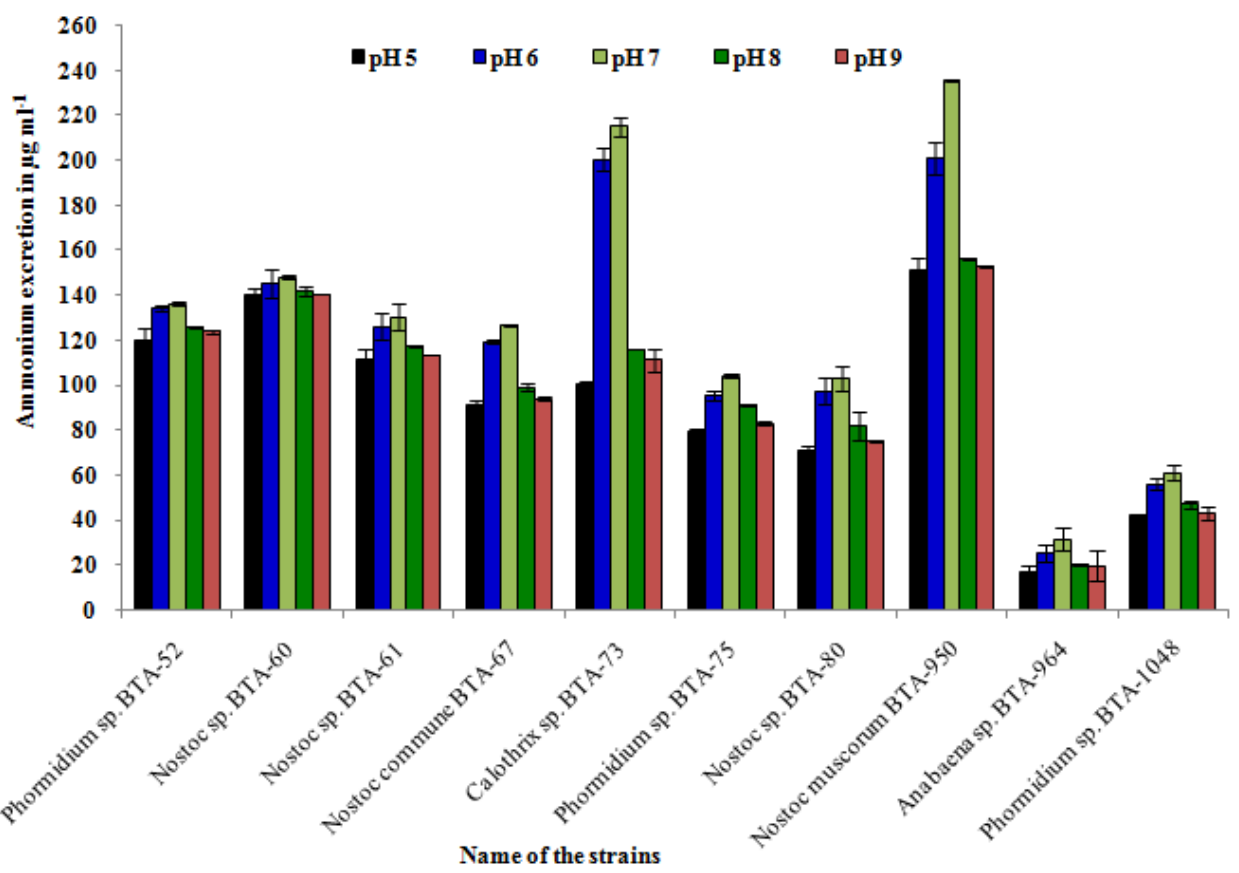

Fig. 2: Effect of different levels of $\mathrm{pH}$ on extracellular ammonium excretion.

related to the limited ability of the cyanobacterium to regulate the internal $\mathrm{pH}$ as the external $\mathrm{pH}$ decreases. Changes in $\mathrm{pH}$ affect various processes such as solubility and bioavailability of nutrients [23], transport of substances across the cytoplasmic membranes, activity of both intra and extracellular enzymes, photosynthetic electron transport and the osmotic potential of the cytoplasm [24]. Low external $\mathrm{pH}$ values may therefore limit cyanobacterial growth by lowering the intracellular $\mathrm{pH}$, by increasing the maintenance energy requirement, by affecting solute transport, or by affecting cell membrane or cell wall biosynthesis [25]. In this study, the observed $\mathrm{pH}$ optimum value for the maximum production of phycobiliprotein is consistent with the values reported for the cyanobacteria Synechocystis [26] and Anabaena NCCU-9 [27]. Among other consequences, an internal $\mathrm{pH}$ drop could lead to the pheophytinization (the displacement of $\mathrm{Mg}^{2+}$ by $2 \mathrm{H}^{+}$) of chlorophyll [28]. The phycobiliproteins produced in the present was found comparable with other reported cyanobacterial strains by [29].

\section{CONCLUSIONS}

The findings indicates that cyanobacterial strains of the present study may be proved as promising microorganism for the industrial applications as source of natural biopigments and biofertilizers. Changes in growth conditions could influence secondary metabolites content in these strains, and a high amount of phycobiliproteins and ammonium excretion can be achieved by combining appropriate factors. Cyanobacteria are imperative source of biopigments that may be exploited biotechnologically for the pharmaceutical industries. From this study, it can be concluded that these cyanobacterial strains from Loktak Lake could be led to further additional research at the genetic level as a potential platform which can be exploited at commercial purposes.

\section{ACKNOWLEDGEMENTS}

The authors gratefully acknowledge the financial support by Indian Council of Agricultural Research (ICAR), Govt. of India. Thanks to Director, IBSD-DBT, for providing required infrastructure. The authors thank the labmates for the kind help during this research work.

\section{CONFLICT OF INTEREST}

The authors declare that they have no conflict of interest.

\section{REFERENCES}

1. Bhaya D, Schwarz R, Grossman AR. Molecular responses to environmental stress. In: Whitton BA, Potts M, editors. The ecology of cyanobacteria: their diversity in time and space, New York: Springer; 2000, p. 397-442.

2. Chu WL. Biotechnological applications of microalgae. International e-Journal of Science, Medicine and Education. 2012; 6:24-37.

3. Cohen Z. Products from microalgae. In: Richmond A, editor. CRC handbook of microalgae mass culture, Boca Raton, Florida, USA: CRC Press; 1986, p. 421-454.

4. Chaneva G, Furnadzhieva S, Minkova K, Lukavsky J. Effect of light and temperature on the cyanobacterium Arthronema africanum- a prospective phycobiliprotein-producing strain. Journal of Applied Phycology. 2007; 19:537-544.

5. Spolaore P, Joannis-Cassan C, Duran E, Isambert A. Commercial applications of microalgae. Journal of Bioscience and Bioengineering. 2006; 101:87-96. 
6. Rodriguez-Sanchez R, Ortiz-Butron R, Blas-Valdivia V, HernandezGarcia A, Cano-Europa E. Phycobiliproteins or C-phycocyanin of Arthrospira (Spirulina) maxima protect against $\mathrm{HgCl}_{2}$-caused oxidative stress and renal damage. Food Chemistry. 2012; 135(4):2359-2365.

7. Venkataraman GS. Blue green algae: a possible remedy to nitrogen scarcity. Current Science. 1981; 50:253-256.

8. Sardeshpande JS, Goyal SK. Effect of $\mathrm{pH}$ on growth and nitrogen fixation by blue green algae. Phykos. 1981; 20:107-113

9. Giraldez-Ruiz N, Mateo P, Bonila I, Fernandez-Pinas F. The relationship between intracellular $\mathrm{pH}$, growth characteristics and calcium in the cyanobacterium Anabaena sp. strain PCC7120 exposed to low pH. New Phytologist. 1997; 137:599-605.

10. Ritchie RJ. Membrane potential and $\mathrm{pH}$ control in the cyanobacterium Synechococcus R- 2 PCC7242. Journal of Plant Physiology. 1991; 137:409-418.

11. Eriksen NT. Production of phycocyanin-a pigment with applications in biology, biotechnology, foods and medicine. Applied Microbiology and Biotechnology. 2008; 80:1-14.

12. Gupta A, Sainis JK. Isolation of C-phycocyanin from Synechococcus sp. (Anacystis nidulans BD1). Journal of Applied Phycology. 2010; 22:231-233

13. Desikachary TV. Cyanophyta. Monograph on Algae. New Delhi, India: ICAR; 1959.

14. Stanier RY, Kunisawa R, Mandel M, Cohen-Bazire G. Purification and properties of unicellular blue-green algae (order Chroococcales). Bacteriology Reviews. 1971; 35(2):171-205.

15. Bennett A, Bogorad L. Complementary chromatic adaptation in a filamentous blue-green alga. Journal of Cell Biology. 1973; 58(2):419-435.

16. Solorzano L. Determination of ammonia in natural waters by the phenol hypochlorite method. Limnology and Oceanography. 1969; 4:799-801.

17. Poza-Carrion C, Fernadez-Valiente E, Fernadez-Pinas F, Leganes F. Acclimation of photosynthetic pigments and photosynthesis of the cyanobacterium Nostoc sp. Strain UAM 206 to combined fluctuations of irradiance, $\mathrm{pH}$ and inorganic carbon availability. Plant Physiology. 2001; 158:1455-1461.

18. Schirrmeister BE, Antonelli A, Bagheri CH. The origin of multicellularity in cyanobacteria. BMC Evolutionary Biology. 2011; 11:45.

19. Montechiaro F, Hirschmugl CJ, Raven JA, Giordano M. Homeostasis of cell composition during prolonged darkness. Plant, Cell and Environment. 2006; 29:2198-2204.
20. Roe S. Protein purification techniques: A practical approach. Oxford, UK: Oxford University Press; 2001.

21. Ripkka R, Dereulles J, Waterbury JB, Herdman M, Stanier RY. Generic assignments, strain histories and properties of pure cultures of cyanobacteria. Journal of General Microbiology. 1979; 111:1-61.

22. Rippka R. Provisional generic assignments of cyanobacteria in pure cultures. In: Starr MP, Stolp H, Truper HC, Balows-Stolp H, Schlegel HG, editors. The prokaryotes, Verlag, Berlin, Heidelberg, New York: Springer; 1981, p. 247-256.

23. Stumn W, Morgan JJ. Aquatic chemistry. 2nd ed. New York: Wiley; 1981

24. Walsby AE. Cell-water and cell-solute relations. In: Carr NG, Whitton BA, editors. The biology of cyanobacteria, Oxford: Blackwell Science Publications; 1982; p. 237-262.

25. Kallas T, Castenholz RW. Internal $\mathrm{pH}$ and ATP-ADP pools in the cyanobacterium Synechococcus sp. during exposure to growthinhibiting low pH. Journal of Bacteriology. 1982a; 149(1):229-236

26. Hong SJ, Lee CG. Statistical optimization of culture media for production of phycobiliprotein by Synechocystis sp. PCC6701. Biotechnology and Bioprocess Engineering. 2008; 13:491-498.

27. Hemlata, Fatma T. Screening of cyanobacteria for phycobiliproteins and effect of different environmental stress on its yield. Bulletin of Environmental Contamination and Toxicology. 2009; 83:509-515.

28. Brock TD. Lower $\mathrm{pH}$ limit for the existence of blue-green algae: evolutionary and ecological implications. Science. 1973; 179:480483.

29. Ranjitha K, Kaushik BD. Purifications of phycobiliproteins from Nostoc muscorum. Journal of Scientific and Industrial Research. $2005 ; 64: 372-375$.

\section{How to cite this article:}

Ojit S.K., Tiwari O.N., Avijeet S.O, Indrama Th., Gunapati O., Sharma G.D. Effect of external $\mathrm{pH}$ on cyanobacterial phycobiliproteins production and ammonium excretion. J App Biol Biotech. 2015; 3 (04): 038-042. 